\title{
BONDING QUALITY OF TWO LESSER-USED WOOD SPECIES Brachystegia spiciformis AND Julbernardia globiflora FROM MOZAMBIQUE
}

\author{
Narciso F. Bila ${ }^{1,2,3, \infty}$ \\ https://orcid.org/0000-0002-1226-5036 \\ Rosilani Trianoski ${ }^{3}$ \\ http://orcid.org/0000-0002-3761-6728 \\ Setsuo Iwakiri ${ }^{3}$ \\ http://orcid.org/0000-0003-0390-3830 \\ Andrade F. Egas ${ }^{2}$ \\ http://orcid.org/0000-0002-1000-5089 \\ Alberto A. Manhiça ${ }^{4}$ \\ https://orcid.org/0000-0002-1639-8418 \\ Márcio P. Da Rocha ${ }^{3}$ \\ http://orcid.org/0000-0002-5420-8478
}

\begin{abstract}
The objective of this study was to evaluate the density, chemical properties and bonding quality of two lesser-used Mozambican wood species known as messassas (Brachystegia spiciformis and Julbernardia globiflora) aiming at edge-glued panel production. The bonding was performed using structural adhesive polyvinyl acetate D4, semi-structural adhesive emulsion polymer isocyanate and non-structural polyvinyl acetate D3 applied at $120 \cdot \mathrm{m}^{-2}$ and $180 \cdot \mathrm{m}^{-2}$ weights. Density, chemistry, edge shear bonding, wood failure percentage and the finger-joint tests were performed in accordance with standards. The results showed that both species have medium density, high extractives and lignin contents typical of tropical wood. The emulsion polymer isocyanate adhesive was approved with better performance compared to polyvinyl acetate D3 and D4 adhesives. It can also be affirmed that Brachystegia spiciformis and Julbernardia globiflora have similar bonding behaviour and the potential for producing edge glued panel panels, especially for indoor use.
\end{abstract}

Keywords: Bonding quality, edge glued panel, emulsion polymeric isocyanate, polyvinyl acetate, value-added products, wood bonding. 


\section{INTRODUCTION}

Concerned about the negative impact of the devastation of the Mozambican forest, characterized by the scarcity of species that have been traditionally used, the national timber sector has been making efforts to raise awareness of the need to better use natural resources from the forest by disseminating sustainability concepts. One of the ways to achieve this goal is to search for options from species that are less known and used in the market, which can contribute in a quantitative and qualitative way to supply the needs of industry and contribute to the development and generation of new higher value-added products. The species Brachystegia spiciformis and Julbernardia globiflora, commonly known as common messassa and red messassa, respectively, account for about $46 \%$ of the total commercial wood available in the country (Magalhães 2018). However, despite their high availability and favourable technological characteristics for industrial use, they are less used in the Mozambican timber industry and their exploitation is below $3 \%$ (DNTF 2017). In addition, the use of messassas is hampered because their properties and performance under different service conditions are less known. From this point of view, it is necessary to conduct a detailed survey of the characteristics of each species to allow their acceptance by the market.

The manufacture of solid wood panels, known as edge-glued panels (EGP), is one of the alternatives uses to add to the value of these species. An EGP is a panel consisting of a set of laterally bonded wood battens, which may or may not have finger-joint top seams and are attached using adhesives (Lopes 2008, Tienne et al. 2011, Iwakiri et al. 2015). EGPs are not yet commercially produced in Mozambique; however, they present the potential for introduction due to the need of the furniture and civil construction sectors, among others. However, to produce EGP, it is very important to know the adhesion capacity of the wood being used, which can be achieved by performing specific loading tests, such as shear on the glue line and percentage of wood failure, to evaluate the efficiency of the union. Wood failure represents the traditional concept of high-quality wood bonding; specifically, it should fail in the adherend to ensure that the adhesive strength surpasses the wood strength (Vick 1999). According to Marra (1992), Shida and Hiziroglu (2010) and Li et al. (2015), the bonding quality of the wood pieces can be influenced by the condition of the surface to be bonded, adhesive and its specifications, weight, pressing method and extractive content, among others. In addition, Conti (2011) and Lopes et al. (2013) state that the most suitable adhesives for the manufacture of EGP and furniture are based on polyvinyl acetate (PVA) and emulsion polymer isocyanate (EPI) due to the low cost and high productivity of PVA, and high glue line strength of EPI.

Regarding PVA based adhesive, Pizzi (1983) states that its formulation can be altered by the incorporation of additives, such as solvents and catalysts, giving rise to different strength classes for this adhesive. The EN 204 (2001) classifies adhesives into distinct durability groups, ranging from D1 to D4 where Class D1 comprises adhesives for indoor use with moisture content below $15 \%$; D2 adhesives for indoor use at humidity below $18 \%$; Class D3 includes adhesives for indoor use with short exposures to moisture and protected outdoor environments; and Class D4 includes adhesives for indoor use with frequent and long term exposure to moisture and outdoor use with adequate protection. According to Pizzi and Mittal (2003), adhesive bonding techniques partially replace traditional joint techniques, reduce weight and ensure a better distribution of forces, offering a better aesthetic with simple, almost invisible glue line.

The objective of this research was to evaluate the basic density, apparent density (12\%), extractive content, $\mathrm{pH}$, lignin content and shear strength of bonded joints and finger-joint seams of two species of messassas from Mozambique, aiming to infer the potential of these species for the production of higher value-added products, such as EGP.

\section{MATERIALS AND METHODS}

\section{Materials}

Two lesser-used wood species from Mozambique, namely Brachystegia spiciformis and Julbernardia globiflora, were tested. The materials were collected in the Acodemuzo community forest concession located in Zambézia province (central region of the country), at Maganja da Costa district, coordinates WSG84 $17^{\circ} 18^{\prime} 22^{\prime}$ 'S, $37^{\circ} 38^{\prime} 26^{\prime} \mathrm{W}$. In total, $15 \mathrm{~B}$. spiciformis and $12 \mathrm{~J}$. globiflora trees with breast height diameter $(1,30 \mathrm{~m})$ ranging from $26 \mathrm{~cm}$ to $55 \mathrm{~cm}$ and averaging $40 \mathrm{~cm}$ were felled and later converted into boards. 6 $\mathrm{mm}$ Thick discs were cut from each tree at the breast height diameter for determination of the basic density and chemical composition (extractives, lignin and $\mathrm{pH}$ ). The bonding tests were performed using structural 
adhesive polyvinyl acetate (PVA D4), emulsion polymer isocyanate (EPI) and non-structural polyvinyl acetate (PVA D3). The PVA D4 adhesive was obtained by adding Aquence 263 catalyst to the PVA D3 adhesive in the ratio of $100 \mathrm{~g}$ to $5 \%$. The adhesives were produced and supplied by Henkel Ltd - Brazil. The properties of the adhesives are shown in Table 1.

Table 1: Properties of the adhesives used in this study.

\begin{tabular}{|c|c|c|c|c|}
\hline Property/adhesive & PVA D3 & PVA D4 & Catalyst & EPI \\
\hline Brookfield Viscosity $-20^{\circ} \mathrm{C}(\mathrm{Cps})$ & $\approx 6000$ & $\approx 6000$ & - & 11000 \\
\hline Solid content $(\%)$ & $42-47$ & $\approx 48$ & 28 & 53 \\
\hline $\mathrm{pH}$ & 4,5 & 3,0 & $<1,0$ & 9,0 \\
\hline & $\approx$ Approximately
\end{tabular}

\section{Methods}

\section{Density and chemical analysis}

The basic density was determined based on ISO 13061-2 (2014) using fifteen $20 \mathrm{~mm}$ x $20 \mathrm{~mm}$ x $50 \mathrm{~mm}$ samples taken from the discs. The apparent density was determined from the ratio between mass and volume of all battens prepared for bonded joints. For the chemical analysis of wood, chips (from the remaining disc material) were produced and then transformed into sawdust, classified into a 60 mesh fraction and tested following the methods described by TAPPI T $204 \mathrm{~cm}$ (2007) (Total extractives in Toluene ethanol), TAPPI 252 (2002) for wood pH, Gomide and Demuner (1986) (insoluble lignin Klason) and Goldschimid (1971) (soluble lignin). The soluble lignin was determined using a SHIMADZU UV - 1800 spectrophotometer at $215 \mathrm{~nm}$ and $280 \mathrm{~nm}$ wavelengths. All chemical analyses were carried out with three replicates.

\section{Top and side bonding test}

The top bonding (finger-joint) test consisted of static bending and tensile tests following the ASTM 5572 (2005) standard. The dimensions of the wood sample for bending were $12,8 \mathrm{~mm} \times 19,2 \mathrm{~mm} \times 307,2 \mathrm{~mm}$ and for tensile were $6,35 \mathrm{~mm} \times 19,05 \mathrm{~mm} \times 254,0 \mathrm{~mm}$, corresponding to thickness, width and length, respectively. Grooves were made at one end of the slats using a profiling cutter, Gautech S-Dum with a $4 \mathrm{~mm}$ pith profile $1,2 \mathrm{~mm}$ tip width and $10 \mathrm{~mm}$ finger length. The slats were assembled by applying the adhesive using a brush to fill the whole length of the finger-joint tooth. The joints were pressed in an industrial pneumatic press for 15 seconds at 0,2 MPa. In this test, only the PVA D3 was used, because it is the most used by the industry for this purpose. Table 2 shows the pre-treatments and experimental design used in this study.

Table 2: Experimental design for top and side bonding of B. spiciformis and J. globiflora wood.

\begin{tabular}{|c|c|c|c|c|c|c|}
\hline \multirow[b]{2}{*}{ Property } & \multirow[b]{2}{*}{ Test } & \multirow[b]{2}{*}{ Adhesive } & \multirow[b]{2}{*}{$\begin{array}{l}\text { Applied glue } \\
\qquad\left(\mathrm{g} \cdot \mathrm{m}^{-2}\right)\end{array}$} & \multicolumn{3}{|c|}{ Pre-treatment } \\
\hline & & & & Dry & E.T & $\begin{array}{c}\text { 3-cycle } \\
\text { soak }\end{array}$ \\
\hline \multirow{2}{*}{ Top bonding } & Bending & \multirow{2}{*}{ PVA D4 } & \multirow{3}{*}{120} & $20^{*}$ & \multirow{2}{*}{20} & \multirow{2}{*}{20} \\
\hline & Tensile & & & & & \\
\hline & & & & Dry & Soak & Boil \\
\hline \multirow{6}{*}{ Side bonding } & \multirow{6}{*}{ Shear strength } & \multirow{2}{*}{ PVA D3 } & 120 & $15^{*}$ & 15 & - \\
\hline & & & 180 & 15 & 15 & - \\
\hline & & \multirow{2}{*}{ PVA D4 } & 120 & 15 & 15 & 15 \\
\hline & & & 180 & 15 & 15 & 15 \\
\hline & & \multirow{2}{*}{ EPI } & 120 & 15 & 15 & 15 \\
\hline & & & 180 & 15 & 15 & 15 \\
\hline
\end{tabular}

Number of the samples; E.T- Elevated temperature. 
For both tests (bending and tensile), the specimens were submitted to three types of pre-treatments: (i) Dry where the set of wood samples were subjected to static bending at moisture content between (12 and 13) \%; (ii) Elevated Temperature, i.e. - the set of wood samples were tested immediately after being kept at (104 \pm 3$)$ ${ }^{\circ} \mathrm{C}$ for six hours and (iii) Three cycles meaning that the samples were soaked in cold water $\left(25^{\circ} \mathrm{C}\right)$ for $4 \mathrm{~h}$ and then dried for $19 \mathrm{~h}$ in an oven at $(41 \pm 3){ }^{\circ} \mathrm{C}$. After the three cycles, the test samples were tested. A universal EMIC assay machine with $20 \mathrm{kN}$ load cell was used to perform both tests. It should be noted that the results of the bending and tensile test were compared only to the minimum requirements of ASTM 5572 (2005).

Regarding the side bonding, 52 battens free of defects and without defined orientation of the cutting planes were produced from the boards for each species. The battens (dimensions of $20 \mathrm{~mm}$ x $55 \mathrm{~mm} \times 310$ $\mathrm{mm}$, for thickness, width and length, respectively) were then dried and conditioned to $12 \%$ moisture content. Bonded joints were obtained by gluing the battens in pairs of two depending on the treatment (species/adhesive/weight).

Adhesive preparation followed the manufacturer's instructions and was applied to one side of the batten and spread with a foam roller to a weight of $120 \mathrm{~g} \cdot \mathrm{m}^{-2}$ and $180 \mathrm{~g} \cdot \mathrm{m}^{-2}$. The specific pressure applied to the battens was $0,6 \mathrm{MPa}$ for $1 \mathrm{~h}$ at room temperature $\left(20^{\circ} \mathrm{C}\right)$ for all adhesives. After pressing, the bonded joints were conditioned in a chamber for seven days to completely cure the adhesive before preparing the wood samples. The wood samples were produced based on EN 13353 (2008) and EN 13354 (2008) and then tested after pre-treatment for indoor use (soak) and outdoor use (boiling), as were specimens without any treatment at a moisture content between $12 \%$ and $13 \%$. 'Soak' samples were pre-treated with cold-water at $20^{\circ} \mathrm{C}$ for $24 \mathrm{~h}$ prior to testing. 'Boil' samples (only for PVA D4 and EPI) were pre-treated for $6 \mathrm{~h}$ in a water bath at $100{ }^{\circ} \mathrm{C}$ followed by cooling for 1 hour in cold water. The shear tests were performed in a universal EMIC brand test machine equipped with a $20 \mathrm{kN}$ load cell. After testing, soak and boiled wood samples were air-dried and then the type of wood failure and lower $5^{\text {th }}$ percentile of the shear strength was determined according to the criteria given by the EN 326-1 (1994).

\section{Data analysis}

Statistical analysis of density, chemical composition and bonding data were performed using the Statgraphics Centurion XVII statistical package (Statgraphics Technologies 2021). An analysis of homogeneity of variances by Bartlet test and $\mathrm{F}$ test in analysis of variance was used in both types of bondings; however, the lateral bonding was in factorial arrangement $(3 \times 2 \times 2)$ considering the variables: adhesive, weight and species, respectively. When the results revealed that there were statistically significant differences between treatment means, they were compared by the "Tukey" test at $95 \%$ confidence level. The data are presented as the mean value and coefficient of variation.

\section{RESULTS AND DISCUSSION}

\section{Wood density and chemical analyses}

The results of density and chemical composition of B. spiciformis and J. globiflora is shown in Table 3 . Both species present mean values statistically equal to basic density $(p \geq 0,05)$, which presupposes a similar behaviour in uses that demand mechanical strength. In addition, considering the values of $670 \mathrm{~kg} \cdot \mathrm{m}^{-3}$ and $680 \mathrm{~kg} \cdot \mathrm{m}^{-3}$ for B. spiciformis and J. globiflora, respectively, they can be classified as medium density wood according to Melo et al. (1990) and Lorenzi (2002), criteria.

Table 3: Density, Extractives, $\mathrm{pH}$ and Lignin content of the species.

\begin{tabular}{|c|c|c|c|}
\hline Parameter & B. spiciformis & J. globiflora & $P^{*}$ \\
\hline Basic density $\left(\mathrm{kg} \cdot \mathrm{m}^{-3}\right)$ & $670_{(6,80)}$ & $680_{(3,25)}$ & 0,2574 \\
\hline Density at $12 \%\left(\mathrm{~kg} \cdot \mathrm{m}^{-3}\right)$ & $740_{(5,54)}$ & $760_{(3,63)}$ & 0,1313 \\
\hline Extractives $(\%)$ & $19,6_{(3,74)}$ & $15,7_{(5,67)}$ & 0,0000 \\
\hline $\mathrm{pH}$ & $6,1_{(6,10)}$ & $6,6_{(8,20)}$ & 0,0209 \\
\hline Klason lignin $(\%)$ & $23_{(15,0)}$ & $30,4(6,4)$ & 0,3272 \\
\hline Soluble lignin $(\%)$ & $0,3_{(9,0)}$ & $0,4_{(12,0)}$ & 0,1220 \\
\hline
\end{tabular}

*A probability value $(p)$ greater than or equal to 0,05 means that there is no significant difference between the means of the species at the $95 \%$ confidence level. The value of the coefficient of variation is in parenthesis. 
According to Marra (1992), Vick (1999) and Gaspar et al. (2005), wood with a basic density below 700 $\mathrm{kg} \cdot \mathrm{m}^{-3}$ tends to present better adhesive bonds and is preferable for the manufacture of EGP panels.

Bunster (1995) estimated a basic density of $590 \mathrm{~kg} \cdot \mathrm{m}^{-3}$ for B. spiciformis, while for $J$. globiflora it was $710 \mathrm{~kg} \cdot \mathrm{m}^{-3}$. The difference of values compared to that found in this research can be explained by the variation that occurs in density as a function of the form and condition of determination, origin, and age within and between trees of the same species. Ali et al. (2008), determined the density (12\%) for the three most common commercial species from Mozambique and obtained $(670,590$ and 720$) \mathrm{kg} \cdot \mathrm{m}^{-3}$ for Afzelia quanzensis (chanfuta), Pterocarpus angolensis (umbila) and Millettia stuhlmannii (jambire). These values show that the studied species have density values (12\%) within the range of commercially used species, and it can be inferred (considering only this property) that they would probably have the same behaviour in service, as alternative species that need to be promoted in the national market and especially in the local furniture industry.

The total extractive content found in this study was higher for B. spiciformis than J. globiflora (Table 3). Sjöström (1981), affirm that the extractive content is generally less than $10 \%$ and, as certain (tropical) species present higher values than this, it increases the difficulty of bonding them. Additionally, Lima et al. (2007) found that the extractives could cause alteration of the wood colouration. Uetimane et al. (2018) determined a total extractive content of $18,5 \%$ for one of the most common commercial tropical species of Mozambique (jambire), while Lhate et al. (2010) reported average values of 9,92 and 11,69\% for the other two commercial species (chanfuta and umbila, respectively). Bila et al. (2016) quantified the total extractive content of six tropical wood species from the Amazon rainforest and found average values ranging from 3,19\% to 11,67 $\%$. High levels of extractives in the wood are undesirable to avoid the negative effect of these components on several processes and products.

The species had average values of $\mathrm{pH}$ outside the $\mathrm{pH}$ range for wood, 3,0 and 5,5 established by Stamm (1964), but, pH values of approximately 6 (as found in this study) can be considered normal and not some extreme (Table 3). However, high $\mathrm{pH}$ values make the species less acidic and, according to Kollmann et al. (1975) and Marra (1992) favours their use for the production of glued products. Based on this assumption, the wood studied is predicted to perform well in bonding.

The average total lignin content for B. spiciformis $(29,6 \%)$ and J. globiflora $(30,8 \%)$ showed statistically equal values. Sangumbe et al. (2018) reported (22,5 $\pm 0,7) \%$ lignin content for Angolan B. spiciformis. These values are within the range of tropical wood lignin established by Fengel and Wegener (1984), which ranges from $29,4 \%$ to $40,5 \%$. Tsoumis (1991) establishes the range of lignin content for hardwoods between $14 \%$ to $34,6 \%$. Lhate et al. (2010) found $26,99 \%$ and $31,10 \%$ Klason lignin for chanfuta and umbila, respectively. Uetimane et al. (2018) estimated a total lignin content of 39,7\% for jambire. A study performed for 36 tropical wood species from Amazonia found a range of lignin content between $26 \%$ and 37\% (Santana and Okino 2007). From this perspective, the results concerning the chemical compositions found in this work may be considered typical for these species. Del Menezzi (2004) emphasized that the lignin content in wood acts as a permanent bonding agent between cells, generating a structure resistant to impact, compression and bending.

\section{Bending and tensile strength of the top bonding test}

The results of bending and tensile strength in top bonding test for indoor use are shown in Table 4 . 
Table 4: Results of bending and tensile strength in top bonding of B. spiciformis and J. globiflora wood.

\begin{tabular}{|c|c|c|c|c|}
\hline Pre-treatments & Species & Bending $(\mathrm{MPa})$ & Tensile $(\mathrm{MPa})$ & $\mathrm{F}_{\mathrm{W}}(\%)$ \\
\hline \multirow{2}{*}{ Dry } & B.spiciformis & $39,1^{\mathrm{a}}{ }_{(9,93)}$ & $30,8^{\mathrm{a}}{ }_{(4,45)}$ & 20 \\
\cline { 2 - 5 } & J. globiflora & $36,4^{\mathrm{a}}{ }_{(5,8)}$ & $29,3^{\mathrm{a}}{ }_{(7,12)}$ & 20 \\
\hline \multirow{3}{*}{ Elevated Temperature } & B.spiciformis & $22,9^{\mathrm{b}}{ }_{(14,13)}$ & $30,6^{\mathrm{a}}{ }_{(9,95)}$ & 17 \\
\cline { 2 - 5 } & J. globiflora & $24,1^{\mathrm{b}}{ }_{(6,86)}$ & $28,6^{\mathrm{b}}{ }_{(11,36)}$ & 22 \\
\hline \multirow{3}{*}{ Three cycles } & B.spiciformis & $31,1^{\mathrm{a}}{ }_{(4,53)}$ & $21,2^{\mathrm{a}}{ }_{(19,16)}$ & 13 \\
\cline { 2 - 5 } & J. globiflora & $25,9^{\mathrm{b}}{ }_{(2,54)}$ & $21,3^{\mathrm{a}}{ }_{(22,74)}$ & 7 \\
\hline
\end{tabular}

Different letters indicate significant differences between species within the pre-treatment $(p<0,05)$ by $\mathrm{t}$-student test; $\mathrm{F}_{\mathrm{w}}-$ wood failure.

According to results in Table 4, in the bending test, the average strength values of the species were statistically equal in dry and high-temperature pre-treatments. The elevated temperature pre-treatment showed lower strength than others. Clau $\beta$ et al. (2011) and Almeida et al. (2017) reported the reduction of MOR values with high-temperature pre-treatment in finger-joints seams using PVA adhesive. The authors state that this situation is due to the prominent thermal degradation of the PVA adhesive starting at $50{ }^{\circ} \mathrm{C}$, which negatively influences the adhesive properties. However, the influence of wood density and adhesive quality (Vick 1999), as well as the geometry and length of the finger-joints (Almeida et al. 2017) should be considered.

It should be noted that ASTM 5572 (2005) establishes comparative values for the static bending test of $13,8 \mathrm{MPa}$ and $6,9 \mathrm{MPa}$ for the dry and 3 cycles tests, respectively. For the test at high temperature, there are no minimum values required. Since, the species have met the minimum requirements of ASTM 5572 (2005) in this test, it demonstrates their suitability for use in finger-joints.

With respect to the tensile test, the strength values ranged from 21,2 $\mathrm{MPa}$ to $30,8 \mathrm{MPa}$ and the highest values were verified in the dry pre-treatment. There was statistical equality in the tensile strength values of both species in the dry and 3-cycles pre-treatment. In a similar study, Molina et al. (2016), found an average value of 23,12 MPa for the tensile strength of Maçaranduba tropical wood (Manilkara huberi) using polyurethane-based single-component Purbond HB 712 structural adhesive. Zangiácomo and Lahr (2007) evaluated finger-joint tensile strength in 4 tropical species and obtained average values between 25,66 $\mathrm{MPa}$ and $54,04 \mathrm{MPa}$ in phenolic (Cascophen) and polyurethane-based adhesives (mamona). It is known that most of the studies of this nature refer to Eucalyptus and Pinus species and there are few on tropical wood with different types of adhesives, which makes it difficult to obtain comparative data.

According to ASTM 5572 (2005), the strength of the hardwood trim in the tensile test should be greater than $13,8 \mathrm{MPa}$ for the dry pre-treatment and the wood failure percentage should be greater than $30 \%$. For pre-treatment at high-temperature and 3 cycles, the strength and wood failure should be higher than $6,9 \mathrm{MPa}$ and $15 \%$ respectively. The requirements established by the ASTM 5572 (2005) for tensile strength were met in both species and pre-treatments. For wood failure, the requirements of the standard were met only in the high-temperature pre-treatment test. It is emphasized that when the average strength values meet the requirements of the standard (regardless of wood failure), it demonstrates a good bonding quality of the finger-joint seams to the tensile stress.

\section{Strength of side bonding to shear tests}

Table 5 shows the average results of maximum shear stress, percentage of failure in the wood and the lower $5^{\text {th }}$ percentile of each species. It is emphasized that according to EN 13354 (2008), when the lower $5^{\text {th }}$ percentile of the shear stress is equal to or greater than $2,5 \mathrm{MPa}$, the species in question is recommended to produce EGP. However, if this condition is not met, the wood failure (evaluated after the shear test) should be above $40 \%$, except when the density of the wood is above $600 \mathrm{~kg} \cdot \mathrm{m}^{-3}$.

Thus, it verified that in the non-pre-treatment test, both species met the requirements of the standard for 
all adhesives with mean shear stress values of $6,86 \mathrm{MPa}$ to $11,82 \mathrm{MPa}$. On the other hand, in the pre-treatment for use in the dry condition, the species met the requirements of the standard only when bonded with EPI in both weights with shear strength values between 3,46 MPa and 6,11 MPa. No species and adhesive satisfied the condition of the standard when pre-treated for outdoor use.

Regarding the percentage of wood failure, B. spiciformis presented higher than $40 \%$ for adhesives PVA D4 and EPI only in the weights of $180 \mathrm{~g} \cdot \mathrm{m}^{-2}$. For $J$. globiflora, there was also wood failure for PVA D4 and EPI adhesives in both weights. The bonded joints with EPI adhesive showed wood failure above 50 $\%$. According to Marra (1992), wood failure equal to or greater than $50 \%$ shows an ideal bonding condition with good adhesive properties and stronger adhesion. Thus, since the average density for the studied species is higher than $600 \mathrm{~kg} \cdot \mathrm{m}^{-3}$, it is not necessary to consider the wood failure as explained above.

Table 5: Shear strength of side bonding for B. spiciformis and J. globiflora wood under different pretreatments.

\begin{tabular}{|c|c|c|c|c|c|c|c|c|c|c|}
\hline \multirow[b]{2}{*}{ Species } & \multirow[b]{2}{*}{$\begin{array}{c}\text { Adhesive } \mathrm{x} \\
\text { weight } \\
\left(\mathrm{g} \cdot \mathrm{m}^{-2}\right)\end{array}$} & \multicolumn{3}{|c|}{ Dry } & \multicolumn{3}{|c|}{ Soak } & \multicolumn{3}{|c|}{ Boil } \\
\hline & & $\begin{array}{l}\text { Shear } \\
\text { strength } \\
(\mathrm{MPa})\end{array}$ & $\begin{array}{l}5^{\text {th }} \mathrm{P} . \\
(\mathrm{MPa})\end{array}$ & $\mathrm{F}_{\mathrm{w}}(\%)$ & $\begin{array}{l}\text { Shear } \\
\text { strength } \\
(\mathrm{MPa})\end{array}$ & $\begin{array}{l}5^{\text {th }} \mathrm{P} . \\
(\mathrm{MPa})\end{array}$ & $\mathrm{F}_{\mathrm{w}}(\%)$ & $\begin{array}{c}\text { Shear } \\
\text { strength } \\
\text { (MPa) }\end{array}$ & $\begin{array}{l}5^{\text {th }} \mathrm{P} . \\
(\mathrm{MPa})\end{array}$ & $\begin{array}{l}\mathrm{F}_{\mathrm{w}} \\
(\%)\end{array}$ \\
\hline \multirow{6}{*}{ B. spiciformis } & PVA D3 x 120 & $6,86_{(22,1)}^{\mathrm{d}}$ & 5,26 & 43 & $1,35^{\mathrm{e}}{ }_{(17,3)}$ & 1,02 & 0 & - & - & - \\
\hline & PVA D4 x 120 & $8,21^{\mathrm{cd}}{ }_{(19,9)}$ & 5,82 & 5 & $1,64_{(24,2)}^{\mathrm{d}}$ & 0,98 & 2 & $0,70^{\mathrm{d}}{ }_{(29,1)}$ & 0,41 & 0 \\
\hline & EPI x 120 & $8,65^{\mathrm{c}}{ }_{(20,8)}$ & 6,03 & 20 & $3,46^{\mathrm{b}}{ }_{(12,0)}$ & 2,58 & 10 & $0,97^{\mathrm{bd}}{ }_{(23,3)}$ & 0,37 & 0 \\
\hline & PVA D3 x 180 & $9,86^{\mathrm{bc}}(8,3)$ & 8,89 & 10 & $1,42^{\mathrm{dc}}(15,9)$ & 0,75 & 3 & - & - & - \\
\hline & PVA D4 x 180 & $9,18^{\mathrm{ab}}{ }_{(16,9)}$ & 6,89 & 11 & $1,94^{\mathrm{c}}{ }_{(21,3)}$ & 1,41 & 3 & $1,14_{(13,0)}^{\mathrm{b}}$ & 0,58 & 10 \\
\hline & EPI x 180 & $11,45^{\mathrm{a}}{ }_{(25,3)}$ & 7,28 & 95 & $5,72^{\mathrm{a}}{ }_{(15,4)}$ & 4,45 & 20 & $1,66^{\mathrm{a}}{ }_{(15,8)}$ & 0,54 & 2 \\
\hline \multirow{6}{*}{ J. globiflora } & PVA D3 x 120 & $7,70_{(13,1)}^{\mathrm{d}}$ & 5,74 & 10 & $1,42^{\mathrm{d}}{ }_{(8,6)}$ & 0,98 & 1 & - & - & - \\
\hline & PVA D4 x 120 & $9,48^{\mathrm{b}}{ }_{(7,82)}$ & 8,54 & 49 & $1,68_{(16,8)}^{\mathrm{d}}$ & 1,22 & 2 & $1,39^{\mathrm{a}}{ }_{(14,1)}$ & 0,50 & 0 \\
\hline & EPI x 120 & $11,51^{\mathrm{a}}{ }_{(21,4)}$ & 8,63 & 60 & $4,27^{\mathrm{b}}{ }_{(19,4)}$ & 3,20 & 10 & $1,18^{\mathrm{ab}}{ }_{(27,8)}$ & 0,73 & 0 \\
\hline & PVA D3 x 180 & $8,58^{\mathrm{bd}}{ }_{(13,9)}$ & 6,80 & 23 & $2,16^{\mathrm{c}}{ }_{(7,4)}$ & 1,18 & 0 & - & - & \\
\hline & PVA D4 x 180 & $9,89^{b}{ }_{(8,7)}$ & 8,70 & 85 & $2,02^{\mathrm{c}}{ }_{(15,8)}$ & 1,68 & 1 & $1,03^{\mathrm{b}}{ }_{(21,8)}$ & 0,66 & 6 \\
\hline & EPI x 180 & $11,82^{\mathrm{a}}{ }_{(14,4)}$ & 9,35 & 56 & $6,11^{\mathrm{a}}{ }_{(17,2)}$ & 2,83 & 4 & $1,52^{\mathrm{a}}(22,7)$ & 0,99 & 11 \\
\hline
\end{tabular}

Means followed by the same letter in a column for each species do not differ by Tukey test $(p<0,05) . \mathrm{F}_{\mathrm{w}}-$ wood failure. $5^{\text {th }} \mathrm{P}$. - Is the lower $5^{\text {th }}$ percentile

The factorial analysis showed that, except for species, the adhesive, weight, double interaction (species $\mathrm{x}$ adhesive) had a significant effect on the shear strength in the side bonding. The individual influence of the variables is discussed (for each specie) in the subsequent analyses and is shown in Table 6 and Table 7.

Table 6: Effect of the type of adhesive and weight on side bonding of B. spiciformis wood.

\begin{tabular}{|c|c|c|c|c|c|c|}
\hline \multirow{2}{*}{ Variable } & \multicolumn{2}{|c|}{ Dry } & \multicolumn{2}{c|}{ Soak } & \multicolumn{2}{c|}{ Boil } \\
\cline { 2 - 7 } & $\begin{array}{c}\text { Shear } \\
\text { strength } \\
(\mathrm{MPa})\end{array}$ & $\begin{array}{c}5^{\text {th }} \mathrm{P} . \\
(\mathrm{MPa})\end{array}$ & $\begin{array}{c}\text { Shear } \\
\text { strength } \\
(\mathrm{MPa})\end{array}$ & $\begin{array}{c}5^{\text {th }} \mathrm{P} . \\
(\mathrm{MPa})\end{array}$ & $\begin{array}{c}\text { Shear } \\
\text { strength } \\
(\mathrm{MPa})\end{array}$ & $\begin{array}{c}5^{\text {th }} \mathrm{P} . \\
(\mathrm{MPa})\end{array}$ \\
\hline \multicolumn{7}{|c|}{ Adhesive } \\
\hline PVA D3 & $8,36^{\mathrm{b}}{ }_{(23,6)}$ & 5,37 & $1,36^{\mathrm{b}}(16,8)$ & 1,08 & - & - \\
\hline PVA D4 & $8,69^{\mathrm{b}}{ }_{(19,3)}$ & 5,63 & $1,72^{\mathrm{b}}{ }_{(25,1)}$ & 1,10 & $0,92^{\mathrm{b}}{ }_{(38,2)}$ & 0,43 \\
\hline EPI & $10,50^{\mathrm{a}}{ }_{(28,5)}$ & 6,31 & $4,59^{\mathrm{a}}{ }_{(30,7)}$ & 2,75 & $1,31_{(61,5)}^{\mathrm{a}}$ & 0,35 \\
\hline \multicolumn{7}{|c|}{ Weight $\left({\left.\mathrm{g} \cdot \mathrm{m}^{-2}\right)}\right.$} \\
\hline 120 & $7,91^{\mathrm{b}}{ }_{(23,3)}$ & 5,39 & $2,81^{\mathrm{a}}{ }_{(51,6)}$ & 1,06 & $0,83^{\mathrm{a}}(41,2)$ & 0,39 \\
\hline 180 & $10,16^{\mathrm{a}}{ }_{(21,7)}$ & 7,53 & $3,00^{\mathrm{a}}(67,8)$ & 1,18 & $1,40^{\mathrm{a}}(53,8)$ & 0,58 \\
\hline
\end{tabular}

Means followed by the same letter in each variable do not differ by Tukey test $(p<0,05) ; 5^{\text {th }} \mathrm{P}$. - Is the lower $5^{\text {th }}$ percentile. 
The analysis of the influence of the type of adhesive (Table 6) demonstrated a better performance of the EPI adhesive in relation to the PVA D3 and D4 adhesives, statistically proven by the higher shear strength in all pre-treatments. It is also observed that there was no statistically significant difference in shear strength between PVA D3 and D4 adhesives. The low performance of the PVA adhesive, mainly in soak and boiling pre-treatments, can be justified by its low resistance when it is exposed to water because it is thermoplastic. According to Grøstad and Pedersen (2010), the main advantages of EPI adhesive are the fast hardening speed, high resistance to moisture and low creep of the glue line. However, given the high cost of the EPI adhesive, it is necessary to carry out further studies with different formulations of the PVA adhesive to verify the suitability of this adhesive in the bonding of the species concerned.

The weight is a variable that directly influences the mechanical strength of a panel, both when using a quantity less than ideal and for a quantity exceeding the recommended one, which must be determined according to the wood species and the final product (Marra 1992, Nascimento et al. 2002). In this study, the weight effect for the B. spiciformis wood was evident only in the dry test (increase of about 2,25 MPa) with statistically different shear strength when changing from $120 \mathrm{~g} \cdot \mathrm{m}^{-2}$ to $180 \mathrm{~g} \cdot \mathrm{m}^{-2}$ (Table 6).

In the soak and boiling pre-treatments, increasing the weight did not result in a statistically significant increase in shear strength. Iwakiri et al. (2019) reported the same weight effect behaviour in bonding the species Eucalyptus camaldulensis (basic density of $820 \mathrm{~kg} \cdot \mathrm{m}^{-3}$ ) and Eucalyptus urophylla (basic density of $720 \mathrm{~kg} \cdot \mathrm{m}^{-3}$ ) in which the increase in weight from $150 \mathrm{~g} \cdot \mathrm{m}^{-2}$ to $180 \mathrm{~g} \cdot \mathrm{m}^{-2}$ resulted in greater shear strength only in the dry test. It is important to note that Teixeira et al. (2014) studied the shear bond strength (dry test) of six Brazilian tropical wood species for four PVA adhesive formulations in weight of $300 \mathrm{~g} \cdot \mathrm{m}^{-2}$ and found average values between 4,1 MPa and 10,6 MPa. The mean values of the present study for the PVA adhesive are also within this range despite the lower weight used. The requirements of standard EN 13354 (2008) were met in this species only when glued with EPI adhesive in the dry and soak test, thus indicating its suitability for the production of EGP panels for internal use.

Table 7 shows the effect of the type of adhesive and weights on side bonding of $\mathrm{t}$ Julbernardia globiflora wood. From Table 7, it can be seen that the EPI adhesive had better performance in all test conditions, for this has higher values of shear strength. It also turns out that the increase in weight resulted in a statistically significant increase in shear strength only in the dry test while in the others (test conditions) it was statistically equal. The effect of both adhesive and weight on side bonding of the J. globiflora wood had the same trend and reasons verified on the $B$. spiciformis wood.

Table 7: Effect of the type of adhesive and weight on side bonding of J. globiflora wood.

\begin{tabular}{|c|c|c|c|c|c|c|}
\hline \multirow{2}{*}{ Variable } & \multicolumn{2}{|c|}{ Dry } & \multicolumn{2}{c|}{ Soak } & \multicolumn{2}{c|}{ Boil } \\
\cline { 2 - 7 } & $\begin{array}{c}\text { Shear } \\
\text { strength } \\
(\mathrm{MPa})\end{array}$ & $\begin{array}{c}5^{\text {th }} \mathrm{P} . \\
(\mathrm{MPa})\end{array}$ & $\begin{array}{c}\text { Shear } \\
\text { strength } \\
(\mathrm{MPa})\end{array}$ & $\begin{array}{c}5^{\text {th }} \mathrm{P} . \\
(\mathrm{MPa})\end{array}$ & $\begin{array}{c}\text { Shear } \\
\text { strength } \\
(\mathrm{MPa})\end{array}$ & $\begin{array}{c}5^{\text {th }} \mathrm{P} . \\
(\mathrm{MPa})\end{array}$ \\
\hline \multicolumn{7}{|c|}{ Adhesive } \\
\hline PVA D3 & $8,08^{\mathrm{c}}{ }_{(15,3)}$ & 5,91 & $2,46^{\mathrm{b}}{ }_{(37,6)}$ & 1,16 & - & - \\
\hline PVA D4 & $9,68^{\mathrm{b}}{ }_{(8,7)}$ & 8,57 & $1,96^{\mathrm{b}}{ }_{(16,3)}$ & 1,71 & $1,03^{\mathrm{b}}{ }_{(32,2)}$ & 0,65 \\
\hline EPI & $11,66^{\mathrm{a}}{ }_{(18,6)}$ & 8,90 & $4,27^{\mathrm{a}}{ }_{(17,2)}$ & 3,20 & $1,52^{\mathrm{a}}{ }_{(22,7)}$ & 0,93 \\
\hline \multicolumn{7}{|c|}{ Weight $\left({\left.\mathrm{g} \cdot \mathrm{m}^{-2}\right)}\right.$} \\
\hline 120 & $8,15^{\mathrm{b}}{ }_{(15,4)}$ & 6,00 & $2,89^{\mathrm{a}}{ }_{(41,9)}$ & 1,11 & $1,27^{\mathrm{a}}{ }_{(38,8)}$ & 0,51 \\
\hline 180 & $9,23^{\mathrm{a}}{ }_{(13,6)}$ & 7,25 & $3,13^{\mathrm{a}}{ }_{(58,8)}$ & 1,63 & $1,29^{\mathrm{a}}{ }_{(32,2)}$ & 0,63 \\
\hline
\end{tabular}

Means followed by the same letter in each variable do not differ statically ( $\mathrm{p} \geq 0,05) ; 5^{\text {th }} \mathrm{P}$. - Is the lower $5^{\text {th }}$ percentile.

The minimum requirements of standard EN 13354 (2008) in J. globiflora wood were met only when bonding with EPI adhesive in the soak test, thus indicating also its suitability for the production of EGP panels for internal use. This result presupposes the negative influence of pre-treatments, especially on the PVA adhesive combined with the intrinsic characteristic of the species. 
Regarding the species (despite the non-statistically significant influence on the side bonding), their presented high extractives content as reported previously. Moslemi (1974) argues that species with high extractive content tend to exhibit a considerable reduction in adhesion strength leading to a poor performance glue line. However, Lima et al. (2007) point out that the reactions between adhesives and extractives depend not only on quantity but also on the type of extractive.

Frihart and Hunt (2010) corroborate that the extractives contribute to the inactivation of the wood surface and, since most wood adhesives are water-based, there is difficulty in wetting and penetrating the adhesive on surfaces covered with extractives. In turn, Almeida (2013) and Bila et al. (2016) evaluated the bonding of tropical wood species and reported the significant influence of the extractive content that the species presented, which was characterized by migration and accumulation of on the surface of the wood, inhibiting adhesive penetration, especially when submitted to pre-treatment.

\section{CONCLUSIONS}

The wood of B. spiciformis and J. globiflora have a basic density suitable for producing EGP panels. Both species present high extractive and lignin contents typical of tropical wood. The average values found for maximum strength of finger-joints in the static bending and tensile tests indicate good bond strength. The percentage of failure in the wood was satisfactory but was impaired by the application of pre-treatment at high temperature and 3 cycles. In side bonding, only the EPI adhesive was approved with better performance compared to PVA D3 and D4 adhesives. The increase in weight from $120 \mathrm{~g} \cdot \mathrm{m}^{-2}$ to $180 \mathrm{~g} \cdot \mathrm{m}^{-2}$ had no significant effect for increasing the edge shear bonding strength. The species B. spiciformis and J. globiflora exhibit similar bonding behaviour and demonstrate a potential for their use in the production of EGP panels for indoor use.

\section{ACKNOWLEDGEMENTS}

The authors thank the Ministry of Science and Technology, Higher Education and Technical-Professional (MCTESTP) of Mozambique for financial support and the project "Forest Research Capacity Strengthening in Mozambique-(FORECAS 2)" held by Natural Resources Finland Institute (Luke) in cooperation with Agrarian Research Institute of Mozambique (IIAM) and the Faculty of Agronomy and Forest Engineering of Eduardo Mondlane University (UEM-FAEF) for valuable assistance. Thanks to Henkel Ltd - Brazil for the adhesive supply.

\section{REFERENCES}

Ali, A.; Uetimane, J.R.; Lhate, I.; Terziev, N. 2008. Anatomical characteristics, properties and use of traditionally used and lesser-known wood species from Mozambique: a literature review. Wood Sci Technol 42(6): 453-472. https://doi.org/10.1007/s00226-008-0186-5

Almeida, V.C. 2013. Assessment of the potential for the use of tropical wood waste for the production of edged glued panels - EGP. PhD thesis, Federal University of Paraná, Brazil. https://acervodigital.ufpr. br/bitstream/handle/1884/34627/R\%20-\%20T\%20-\%20VANESSA\%20COELHO\%20ALMEIDA.pdf?sequence $=1 \&$ is Allowed $=\mathrm{y}$

Almeida, C.C.F.; Cunha, A.B.; Rios, P.D. 2017. Quality evaluation of Cupressus lusitanica Mill. wood end-grain glued joints for edge glued panel production. Sci For 45(113): 9-19. https://www.ipef.br/publicacoes/scientia/nr113/cap01.pdf

ASTM. 2005. Standard specification for adhesives used for finger joints in nonstructural lumber products ASTM D 5572 - 95. West Conshohocken: United States. 15p.

Bunster, J.H. 1995. 52 madeiras de Mocambique. Catalogo tecnológico. Eduardo Mondlane University: Maputo, Mozambique.

Bila, N.; Iwakiri, S.; Trianoski, R.; Prata, J.G. 2016. Avaliação da qualidade de juntas coladas de seis espécies de madeiras tropicais da Amazônia. Floresta 46(4): 455-464. http://dx.doi.org/10.5380/rf.v46i4.36311

Clauß, S.; Joscak, M.; Niemz, P. 2011. Thermal stability of glued wood joints measured by shear tests. European Journal of Wood and Wood Products 69(1): 101-111. https://doi.org/10.1007/s00107-010-0411-4 
Conti, A.C. 2011. Resistência mecânica de juntas coladas em madeira de Eucalyptus sp. PhD thesis, Estadual Paulista University, Guaratinguetá, Brazil. https://repositorio.unesp.br/bitstream/handle/11449/103751/ deconti_ac_dr_guara.pdf?sequence=1\&isAllowed=y

Del Menezzi, C.H.S. 2004. Estabilização dimensional por meio do tratamento térmico e seus efeitos sobre as propriedades de painéis de partículas orientadas (OSB). Ph.D Thesis, Paraná Federal University, Brazil. https://acervodigital.ufpr.br/bitstream/handle/1884/26735/T\%20-20DEL\%20MENEZZI\%2c\%20CLAUDIO\%20HENRIQUE\%20SOARES.pdf?sequence=1\&isAllowed=y

Direção Nacional de Terras e Florestas. DNTF. 2017. Exploração Sustentável da Madeira em Moçambique. Maputo, Mozambique.

EN.1994. Sampling, cutting and inspection of wood-based panel products - Sampling and cutting of test pieces and expression of test results. EN 326-1.1994. ECS: Brussels.

EN. 2008. Solid wood panel - Requirements. EN 13353. 2008. ECS: Brussels.

EN. 2008. Solid wood panels - Bonding quality - Test Method. EN 13354. 2008. ECS: Brussels.

Fengel, D.; Wegener, G. 1984. Wood Chemistry, ultrastructure reactions. 2nd Edition, Walter de Gruyter: Berlin, Germany.

Frihart, C.R.; Hunt, C.G. 2010. Adhesives with Wood Materials: Bond Formation and Performance. U.S. Department of Agriculture, Forest Service: Madison United States. https://www.srs.fs.usda.gov/pubs/37422

Gaspar, F.; Cruz, H.; Nunes, L.; Gomes, A. 2005. Fabrico de Estruturas Lameladas - Coladas com madeira de Pinho Bravo tratado em autoclave. In $5^{\circ}$ Congresso Florestal Nacional, vol. 16. https://www.academia. edu/6313133/Fabrico_de_estruturas_lameladas coladas_com_madeira_de_pinho_bravo_tratada_em_autoclave

Goldschimid, O. 1971. Ultraviolet spectra. In Lignin's: occurrence, formation, structure and reactions. Sarkanen, K.V; Ludwing, C.C. (Eds.). John Wiley \& Sons: New York, United States, pp. 241-266

Gomide, J.L.; Demuner, B.J. 1986. Determination of lignin content in woody material: Modified Klason method. O Papel 47: 36-38.

Grostad, K.; Pedersen A. 2010. Emulsion Polymer Isocyanates as Wood Adhesive: A Review. J Adhes Sci Technol 24(8-10): 1357-1381. https://doi.org/10.1163/016942410X500981

ISO. 2014. Physical and mechanical properties of wood - Test methods for small clear wood samples. Determination of density for physical and mechanical tests. ISO 13061-2. 2014. Switzerland.

Iwakiri, S.; Trianoski, R.; Nascimento, C.; Gumane, C.; Lengowski, E.C.; Schardosin, F.Z.; Azambuja, R. 2015. Strength of bonded wood joints of Inga alba (SW) Willd and Swartzia recurva Poepp. Cerne 21(3): 457-463. http://www.cerne.ufla.br/site/index.php/CERNE/article/view/1092

Iwakiri S.; Trianoski, R.; Stüpp, A.M.; Cabral, B.M.; Jéssika, G.J.A.C.A. 2019. The Use of Eucalyptus camaldulensis and Eucalyptus urophylla wood in the production of edge glued panels. Floresta 49(2):317324. http://dx.doi.org/10.5380/rf.v49i2.57795

Kollmann, F.P.; Kuenzi, E.W.; Stamm, A.J. 1975. Principles of wood science and technology. Volume 2, wood based material. Springer: Berlin, Germany.

Li, R.; Guo, X.; Ekevand, M.; Marklund, B.; Cao, P. 2015. Investigation of glueline shear strength of pine wood bonded with PVAc by response surface methodology. Bioresources 10(3): 3831-3838. https://ojs.cnr.ncsu.edu/index.php/BioRes/article/view/6826

Lima, C.K.P.; Mori, F.A.; Mendes, L.M.; Carneiro, A.C.O. 2007. Características anatômicas e química da madeira de clones de eucaliptos e sua influência na colagem. Cerne 13(2): 123-129. https://www.redalyc. org/pdf/744/74413201.pdf

Lhate, I.; Cuvilas, C.; Terziev, N.; Jirjis, R. 2010. Chemical compositions of traditional and lesser-used species from Mozambique. Wood Mater Sci Eng 5(3-4): 143-150. https://doi.org/10.1080/17480272.2010.48 4867

Lopes, M.C. 2008. Espectroscopia no infravermelho próximo aplicada na avaliação de painéis de madeira colados lateralmente. PhD thesis, Federal University of Paraná, Brazil. https://pt.scribd.com/document/318950526/Espectroscopia-no-infravermelho-proximo-aplicada-na-avaliacao-de-paineis-de-madeira-colados-lateralmente 
Lopes, M.C.; Muniz, G.I.B.; Matos, J.L.M.; Tanobe, V.O.A.; Chinasso, C.A.F.; Rosso, S. 2013. Resistência da linha de cola de painéis de Pinus taeda colados lateralmente com diferentes adesivos. Cerne 19(4): 613-619. https://doi.org/10.1590/S0104-77602013000400011

Lorenzi, H. 2002. Árvores brasileiras: manual de identificação e cultivo de plantas arbóreas nativas do Brasil. Nova Odessa, Instituto Plantarum de Estudos da Flora Ltda: Brazil.

Magalhães, T. 2018. Inventário Florestal Nacional. MITADER. DINAF. Maputo, Mozambique.

Marra, A.A. 1992. Technology of wood bonding. Van Nostrand Reinhold: New York, United States.

Melo, J.E.; Coradin, V.T.R.; Mendes, J.C. 1990. Classes de densidade para madeira da Amazônia brasileira. Silvicultura 12 (42): 695-699. https://n9.cl/t0c1

Molina, J.C.; Calil Neto, C.; Christoforo, A.L. 2016. Resistência à tração de emendas dentadas de madeira de Manilkara huberi para o emprego em madeira laminada colada. Ambient Constr 16(1): 221-227. https://doi.org/10.1590/s1678-86212016000100070

Moslemi, A.A. 1974. Particleboard. London: Southern Illinois University Press: London, United States.

Nascimento, A.M.; Lellis, R.C.C.; Costa, D.L.; Oliveira, C.S. 2002. Comportamento de ligações adesivas em madeiras de reflorestamento. Floram 9(1): 54- 62. https://floram.org/article/588e21fde710ab87018b$45 \mathrm{db}$

Pizzi, A. 1983. Wood Adhesives Chemistry, Technology, Vol. 12. Marcel Dekker, New York: Unites States.

Pizzi, A.; Mittal, K.L. 2003. Handbook of adhesive technology. 2 Ed. Marcel Deckker: New York, United States. https://polymerinnovationblog.com/wp-content/uploads/2015/02/handbook-of-adhesive-technology. pdf

Shida, S.; Hiziroglu, S. 2010. Evaluation of Shear Strength of Japanese Wood Species as a Function of Surface Roughness. Forest Prod J 60(4): 400 - 404. https://doi.org/10.13073/0015-7473-60.4.400

Sangumbe, L.M.V.; Pereira, M.; Carrilo, I.; Mendoça, R.T. 2018. An exploratory evaluation of the pulpability of Brachystegia spiciformis and Pericopsis angolensis from the angolan miombo woodlands. Maderas-Cienc Tecnol 20(2): 183-198. http://dx.doi.org/10.4067/S0718-221X2018005002301

Santana, M.A.E.; Okino, E.Y.A. 2007. Chemical composition of 36 Brazilian Amazon forest wood species. Holzforschung 61(5): 469-477. https://doi.org/10.1515/HF.2007.084

Sjöström, E. 1981. Wood chemistry: fundamentals and applications. $2^{\circ}$ Ed. Academic Press: San Diego, United States

Stamm, A.J. 1964. Wood and cellulose science. The Ronald Press Company: New York. United States.

Statgraphics Technologies. 2021. Statgraphics XVII statistical package. https://www.statgraphics.com/

TAPPI. 2007. Test methods. TAPPI 204. 2007. 2nd Volume. TAPPI Press: Atlanta. United States.

TAPPI. 2002. $\mathrm{pH}$ and electrical conductivity of hot water extracts of pulp, paper, and paperboard. TAPPI 252. 2002. TAPPI Press: Atlanta. United States.

Teixeira, D.E.; Melo, J.E.; Anacleto, J.E. 2014. Testing quality of compression bonding to shearing on six Brazilian hardwood species. Sci For 42(103): 393-401. https://www.ipef.br/publicacoes/scientia/nr103/ cap09.pdf

Tienne, D.L.D.C.; Nascimento, A.M.; Garcia, R.A.; Silva, D.B. 2011. Qualidade de adesão de juntas de madeira de Pinus coladas em condições simuladas de serviço interna e externa. Floram 18(1): 16-29. http://dx.doi.org/10.4322/floram.2011.019

Tsoumis, G. 1991. Science and technology of wood: structure, properties and utilization. Van Nostrand Reinhold: New York, Unites States.

Uetimane, E.Jr.; Jebrane, M.; Terziev, N.; Daniel, G. 2018. Comparative wood Anatomy and Chemical Composition of Millettia mosssambicensis and Millettia sthulmannii from Mozambique. BioResources 13(2): 3335-3345. https://ojs.cnr.ncsu.edu/index.php/BioRes/article/view/13200

Vick, C.B. 1999. Adhesive Bonding of Wood Materials. In Wood handbook - Wood as an engineering material, (USDA) Forest Service. Chapter 9: 1-9. Madison, Wisconsin, United States. https://www.fpl.fs.fed. us/documnts/fplgtr/fplgtr113/fplgtr113.pdf 
Zangiácomo, A.L.; Lahr, F.A.R. 2007. Emprego de espécies tropicais alternativas na produção de elementos estruturais de madeira laminada colada. Cadernos de Engenharia de Estruturas 9(40): 103-131. 